\title{
Intraoperative prediction of non-sentinel lymph node metastases in breast cancer using cytokeratin 19 mRNA copy number: A retrospective analysis
}

\author{
HELOÏSE PINA $^{1}$, JULIA SALLERON ${ }^{2}$, PAULINE GILSON ${ }^{1,3}$, MARIE HUSSON ${ }^{1}$, MARIE ROUYER ${ }^{1}$, \\ AGNES LEROUX ${ }^{1}$, PHILIPPE RAUCH ${ }^{4}$, FREDERIC MARCHAL ${ }^{3,4}$, MATHILDE KÄPPELI $^{3}$, \\ JEAN-LOUIS MERLIN ${ }^{1,3}$ and ALEXANDRE HARLÉ ${ }^{1,3}$
}

\author{
Départements de ${ }^{1}$ Biopathologie, ${ }^{2}$ Biostatistique, Institut de Cancérologie de Lorraine, F-54519 Vandœuvre-lès-Nancy; \\ ${ }^{3}$ Université de Lorraine, CNRS UMR 7039 CRAN; ${ }^{4}$ Département de Chirurgie, \\ Institut de Cancérologie de Lorraine, F-54519 Vandœuvre-lès-Nancy, France
}

Received March 29, 2021; Accepted October 10, 2021

DOI: $10.3892 / \mathrm{mco} .2022 .2491$

\begin{abstract}
One-step nucleic acid amplification (OSNA) is a molecular procedure used intraoperatively for the detection of sentinel lymph node (SLN) metastases. The aim of the present study was to define a cut-off of cytokeratin (CK)19 mRNA copy number predictive of positive completion axillary lymph node dissection (ALND). The OSNA procedure was employed for SLN analysis in 812 patients with T1-T2 N0 breast cancer. A total of 197 patients with SLN metastases were retrospectively analyzed. A total of 40 patients $(20 \%)$ had non-SLN metastases. Receiver operating characteristics curve analysis established a cut-off of 5,000 CK19 mRNA copy number with $75 \%$ sensitivity and $72 \%$ specificity. The positive and negative predictive values were 40.5 and $92 \%$, respectively. Multivariate analysis showed that this cut-off and tumor localization in the outer or lower-outer quadrant of the breast were significantly associated with non-SNL involvement $(\mathrm{P}<0.001$ and $\mathrm{P}=0.025$, respectively). The findings of the present study support the conventional cut-off of 5,000 copies for intraoperative decision to perform ALND, whereas ALND can safely be avoided in patients with tumor located outside the outer or lower-outer quadrant of the breast if the CK19 mRNA copy number is $<5,000$.
\end{abstract}

\section{Introduction}

Breast cancer is the most common malignancy in women, accounting for 627,000 deaths worldwide in 2018 (1). Lymph

Correspondence to: Professor Alexandre Harlé, Département de Biopathologie, Institut de Cancérologie de Lorraine, 6 Avenue de Bourgogne, CS 30519, F-54519 Vandœuvre-lès-Nancy, France E-mail: a.harle@nancy.unicancer.fr

Key words: breast cancer, one-step nucleic acid amplification, sentinel lymph node node involvement is one of the most important prognostic factors in breast cancer (2). Axillary lymph node dissection (ALND) significantly reduces recurrence and improves regional control and nodal staging, which is important for the selection of adjuvant therapy (3) and prognostic evaluation (4). However, ALND is associated with various adverse side effects, such as lymphedema, numbness, chronic pain, seroma or infection, and its impact on survival and recurrence is subject to controversy $(5,6)$.

Sentinel lymph node biopsy (SLNB) is a common procedure used to detect the presence of metastatic cells and to decide whether ALND is required. SLNB may also help with breast cancer staging (7). Histological examination of step section or serial section slides of SLNs is the most widely used method. One-step nucleic acid amplification (OSNA; Sysmex Corporation) is an alternative loop-mediated isothermal amplification (LAMP)-based semi-quantitative assay that quantifies copies of cytokeratin (CK)19 mRNA, which is expressed in most breast cancer cells (8). The determination of CK19 mRNA copy number can predict the presence of microor macro-metastases in the SNL (9). Several studies have shown that OSNA is more sensitive and objective compared with histological examination (10). It is also a cost-effective strategy $(11,12)$ that is widely used in Europe and Japan $(13,14)$.

OSNA is an intraoperative procedure; therefore, ALND can be performed during the same surgery, thereby avoiding a second surgery. The OSNA procedure also makes it possible to commence adjuvant treatment earlier (15). It is also important to identify patients in whom ALND can safely be avoided, without increasing the risk of recurrence $(16,17)$.

The aim of this retrospective study was to determine whether CK19 mRNA copy number in the SNL could predict positivity of ALND.

\section{Materials and methods}

Studypopulation. A total of 812 patients with early-stage invasive breast cancer underwent breast surgery, SNL biopsy and OSNA analysis between January 2010 and August 2014 at the Institut 
de Cancérologie de Lorraine (ICL; Vandoeuvre-lès-Nancy, France). Surgery and OSNA procedures were decided for all patients with clinically or ultrasonographically node-negative cT1-2 breast cancer. All patients provided informed oral consent and a signed a non-opposition form and the study was approved by the Ethics Committee of the ICL (CAV-2009-osna).

The exclusion criteria were as follows: i) Patients who had received neoadjuvant treatment, had undergone previous ipsilateral breast or axillary surgery, had cT3-T4 tumors, and clinically or ultrasonographically positive axilla confirmed by fine-needle aspiration biopsy; ii) a total of 20 patients were excluded due to positive inhibition status (+I), corresponding to values greater than the highest point of the calibration curve, making the determination of exact number of copies not possible; and iii) a total of 49 patients were also excluded as one central slice of their SLNs had been investigated by histology, potentially decreasing the number of copies of CK19 mRNA detected. Data collected from each patient are listed in Table I. Data for the current study were obtained from the prospective breast cancer database at the ICL. All data were anonymized prior to analysis to protect patient confidentiality.

SLN biopsy procedure. SLNs were localized using the isotope method, alone or combined with the dye procedure. The isotope method consisted of ${ }^{99 \mathrm{~m}} \mathrm{Tc}$-labeled rhenium sulfur (Amersham; Cytiva) periareolar injection the day before surgery, followed by lymphoscintigraphy 1-3 $\mathrm{h}$ later. The dye procedure consisted of $2 \mathrm{ml}$ of patent blue dye (Guerbet) administered by subareolar injection at surgery. SLNs were identified using a hand-held gamma-probe (Europrobe 3; Euromedical Instruments), isolated, and perinodal fat was removed. All suspicious lymph nodes identified during surgery were sent for analysis. Data on the SLNs included their color (blue or not), localization, signal intensity and size.

Lymph nodes with a weight of $>0.6 \mathrm{~g}$ were subdivided into two or more samples and processed separately, as recommended by the manufacturer of the OSNA assay (Sysmex Corporation). A maximum of 4 samples were assessed per run, for a total running time of 15-60 min for 1-4 samples, respectively.

Histopathology. Each non-SNL was measured, cut longitudinally into $2-\mathrm{mm}$ sections, fixed in formalin for $8 \mathrm{~h}$ at room temperature and embedded in paraffin. The sections were then prepared for hematoxylin and eosin staining.

Breast tumors were examined by hematoxylin and eosin staining. CK19 (clone RCK 108; cat. no. M0888; Agilent Technologies, Inc.), hormonal receptors, including estrogen receptor (ER; clone SP1; cat. no. 790-4325) and progesterone receptor (PR; clone 1E2; cat. no. 790-4296; Ventana Medical Systems, Inc.; Roche Diagnostics), HER2 (clone 4B5; cat. no. 790-4493; Ventana Medical Systems, Inc.; Roche Diagnostics) and Ki-67 (clone MIB-1; cat. no. M7240; Agilent Technologies, Inc.) expression were determined using immunohistochemistry. All assays were automated using Benchmark (Roche Diagnostics) according to the manufacturer's protocols. Histopathological categories were defined according to the sixth edition of the TNM classification (18).

OSNA analysis and mRNA CK19 copy determination. The OSNA assay was processed as previously described using the OSNA BC System (Sysmex Corporation) (9). Briefly, whole SLNs were homogenized in $4 \mathrm{ml}$ Lynorhag lysis buffer (Sysmex Corporation). The homogenate was centrifuged at $10,000 \mathrm{x} \mathrm{g}$ for $1 \mathrm{~min}$ at room temperature and directly used as a template for amplification. CK19 mRNA detection was assessed using reverse transcription-LAMP with the RD-100i analyzer (Sysmex Corporation).

Results for each sample were presented on the RD-100i instrument in qualitative categories along with the CK19 mRNA copy number/ $\mu 1$. The (-), (+), (++) and (+I) symbols were used by the OSNA instrument to indicate copy numbers of $<250,250-5,000,>5,000$ and greater than the highest point of the standard curve, respectively.

According to the cut-off levels defined by Tsujimoto etal (9), a copy number between 250 and 5,000 copies/ $\mu 1$ (+) was considered as predictive of the presence of SLN micrometastases in the analyzed lymph node, and a copy number $>5,000 / \mu 1(++)$ was considered as predictive of the presence of SLN macrometastases. A copy number $<250$ copies/ $\mu 1$ was considered as predictive of the absence of tumor cells.

The number of copies was then estimated using the number of copies measured in a $1 / 10$ dilution of the sample. The node total copy number was estimated by adding CK19 mRNA copies of each piece of the sample, in nodes weighing $>0.6 \mathrm{~g}$. Tubes containing more than one node for the same patient were excluded from the analysis. Only the SLN with the highest number of copies was considered for each patient.

Statistical analysis. Statistical analysis was performed using SAS software version 9.4 (SAS Institute Inc.). The significance levelwas setat 0.05 .Qualitative variablesare describedas number and percentage, and quantitative variables as mean \pm standard deviation, or median and interquartile range (IQR), according to the normality test (Kolmogorov-Smirnov test). Predictive factors of positive ALND were investigated using bivariate logistic regression and the results are expressed as ORs and 95\% CIs. The log-linearity assumption of the logistic model was checked by categorizing each variable in 10 groups (corresponding to deciles) and by examining the plots of the logit of observed percentages of positive ALND in each class. Quantitative variables were transformed into binary variables if the log-linearity assumption was violated, using the threshold maximizing sensitivity and specificity (Youden index). All variables with a P-value $<0.10$ in bivariate logistic regression were included in a multivariate logistic regression model with backward selection at $\mathrm{P}=0.10$. The results of the final multivariate model are presented as adjusted ORs (95\% CIs). The stability of the selected model was investigated using the bootstrap resampling method (19).

\section{Results}

Study population. Among the 812 patients who underwent OSNA analysis, 246 patients had at least one positive SLN. Among these, a total of 197 patients with positive OSNA analysis were included in this retrospective study (Fig. 1). A comparison of the characteristics of included $(n=197)$ vs. excluded $(n=615)$ patients is presented in Table I. Patient and disease characteristics are summarized in Table II. Patients with SLN micro- or macrometastases as determined by OSNA 
Table I. Comparison of clinicopathological characteristics between the included and the excluded patients.

\begin{tabular}{|c|c|c|c|c|}
\hline Characteristics & $\begin{array}{l}\text { All patients }(\mathrm{n}=812) \text {, } \\
\mathrm{n}(\%)\end{array}$ & $\begin{array}{c}\text { Included }(\mathrm{n}=197) \\
\mathrm{n}(\%)\end{array}$ & $\begin{array}{c}\text { Excluded }(\mathrm{n}=615) \\
\mathrm{n}(\%)\end{array}$ & P-value \\
\hline Age, years (mean $\pm \mathrm{SD})$ & $60 \pm 11$ & $59 \pm 11$ & $61 \pm 12$ & 0.264 \\
\hline Body mass index $\geq 30 \mathrm{~kg} / \mathrm{m}^{2}$ & $170(20.9)$ & $42(21.3)$ & $128(20.8)$ & 0.879 \\
\hline Tumor size $\geq 13 \mathrm{~mm}$ & $377(46.4)$ & $111(56.3)$ & $266(43.2)$ & 0.001 \\
\hline \multicolumn{5}{|c|}{ Bloom-Richardson histological grade } \\
\hline 1 & $229(29.6)$ & $59(30.3)$ & $170(29.4)$ & \multirow[t]{3}{*}{0.787} \\
\hline 2 & $397(51.3)$ & $102(52.3)$ & $295(50.9)$ & \\
\hline 3 & $148(19.1)$ & $34(17.4)$ & $114(19.7)$ & \\
\hline \multicolumn{5}{|l|}{ Tumor localization } \\
\hline Outer or lower-outer quadrant & $165(20.7)$ & $35(17.8)$ & $130(21.6)$ & \multirow[t]{2}{*}{0.245} \\
\hline Other & $633(79.3)$ & $162(82.2)$ & $471(78.4)$ & \\
\hline \multicolumn{5}{|l|}{ Histological type } \\
\hline Ductal & $598(73.6)$ & $153(77.7)$ & $445(72.4)$ & \multirow[t]{3}{*}{0.070} \\
\hline Lobular & $76(9.4)$ & $21(10.7)$ & $55(8.9)$ & \\
\hline Other & $138(17.0)$ & $23(11.7)$ & $115(18.7)$ & \\
\hline Positive ER status & $742(91.4)$ & $183(92.9)$ & $559(90.9)$ & 0.384 \\
\hline Positive PR status & $635(78.2)$ & $156(79.2)$ & $479(77.9)$ & 0.700 \\
\hline Positive ER and/or PR status & $751(92.5)$ & $183(92.3)$ & $568(92.5)$ & 0.804 \\
\hline Positive HER2 receptor status & $52(6.4)$ & $13(6.6)$ & $39(6.3)$ & 0.898 \\
\hline Triple-negative breast cancer & $47(5.8)$ & $12(6.1)$ & $35(5.7)$ & 0.834 \\
\hline $\begin{array}{l}\text { Sentinel lymph nodes removed, } \\
\text { median (range) }\end{array}$ & $3(2-4)$ & $2(2-4)$ & $3(2-4)$ & 0.081 \\
\hline
\end{tabular}

ER, estrogen receptor; PR, progesterone receptor; HER2, human epidermal growth factor receptor.

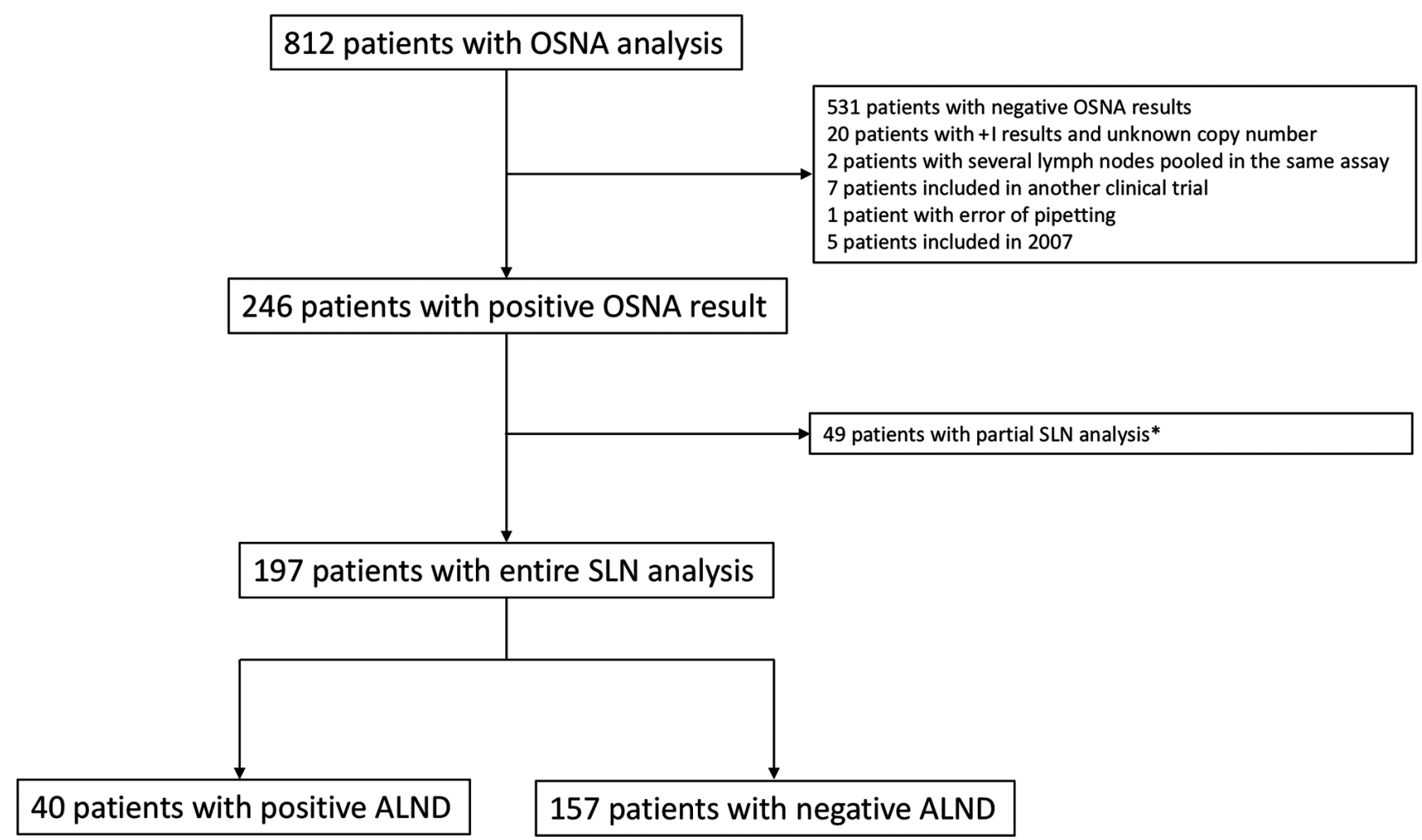

Figure 1. Study workflow diagram. Among the 812 patients who underwent OSNA analysis, 246 patients had at least one positive SLN. Among these, a total of 197 patients with positive OSNA analysis were included in this retrospective study. OSNA, one-step nucleic acid amplification; SLN, sentinel lymph node; ALND, axillary lymph node dissection. *, patients were excluded if the lymph node was analyzed only partially. 
Table II. Clinicopathological characteristics for the 197 patients and according to the positivity of ALND.

\begin{tabular}{|c|c|c|c|c|}
\hline Characteristics & $\begin{array}{c}\text { All patients } \\
(\mathrm{n}=197), \mathrm{n}(\%)\end{array}$ & $\begin{array}{l}\text { Negative ALND } \\
(\mathrm{n}=157), \mathrm{n}(\%)\end{array}$ & $\begin{array}{l}\text { Positive ALND } \\
(\mathrm{n}=40), \mathrm{n}(\%)\end{array}$ & P-value \\
\hline Age, years $($ mean $\pm \mathrm{SD})$ & $59 \pm 11$ & $60 \pm 11$ & $58 \pm 13$ & 0.296 \\
\hline Body mass index $\geq 30 \mathrm{~kg} / \mathrm{m}^{2}$ & $42(21.3)$ & $29(18.5)$ & $13(32.5)$ & 0.053 \\
\hline Tumor size $\geq 13 \mathrm{~mm}^{\mathrm{a}}$ & $111(56.3)$ & $82(52.2)$ & $29(72.5)$ & 0.021 \\
\hline Bloom-Richardson histological grade & & & & 0.548 \\
\hline 1 & $59(30.3)$ & $49(31.6)$ & $10(25.0)$ & \\
\hline 2 & $102(52.3)$ & $78(50.3)$ & $24(60.0)$ & \\
\hline 3 & $34(17.4)$ & $28(18.1)$ & $6(15.0)$ & \\
\hline Tumor localization & & & & 0.023 \\
\hline Outer or lower-outer quadrant & $35(17.8)$ & 23 (14.6) & $12(30.0)$ & \\
\hline Other & $162(82.2)$ & $134(85.4)$ & $28(70)$ & \\
\hline \multicolumn{5}{|l|}{ Histological type } \\
\hline Ductal & $153(77.7)$ & $118(75.2)$ & $35(87.5)$ & 0.144 \\
\hline Lobular & $21(10.7)$ & $20(12.7)$ & $1(2.5)$ & \\
\hline Other & $23(11.7)$ & $19(12.1)$ & $4(10.0)$ & \\
\hline Positive ER status & $183(92.9)$ & $145(92.4)$ & $38(95.0)$ & 0.739 \\
\hline Positive PR status & $156(79.2)$ & $121(77.1)$ & $35(87.5)$ & 0.147 \\
\hline Positive ER and/or PR status & $183(92.3)$ & $145(92.4)$ & $38(95.0)$ & 0.739 \\
\hline Positive HER2 receptor status & $13(6.6)$ & $11(7.0)$ & $2(5.0)$ & 1 \\
\hline Triple-negative breast cancer & $12(6.1)$ & $10(6.4)$ & $2(5.0)$ & 1 \\
\hline SLNs removed, median (range) & $2(2-4)$ & $2(2-3)$ & $2.5(2-4)$ & 0.38 \\
\hline Positive SLNs, median (range) & $1(1-1)$ & $1(1-1)$ & $1(1-2)$ & 0.23 \\
\hline 1 & $147(74.8)$ & $121(77.1)$ & $26(65.0)$ & \\
\hline 2 & $39(19.4)$ & $30(19.1)$ & $9(22.5)$ & \\
\hline 3 & $10(5.2)$ & $6(3.8)$ & $4(10.0)$ & \\
\hline 4 & $1(0.6)$ & 0 & $1(2.5)$ & \\
\hline $\begin{array}{l}\text { SLN maximal copy number } / \mu 1 \text {, } \\
\text { median (range) }\end{array}$ & $2,100(540-38,000)$ & $1,300(530-6,900)$ & $60,830(5,000-695,000)$ & $<0.001$ \\
\hline$\geq 4,700^{\mathrm{a}}$ & $77(39.1)$ & $46(29.3)$ & $31(77.5)$ & $<0.001$ \\
\hline$\geq 5,000$ & $74(37.6)$ & $44(28.0)$ & $30(75.0)$ & $<0.001$ \\
\hline
\end{tabular}

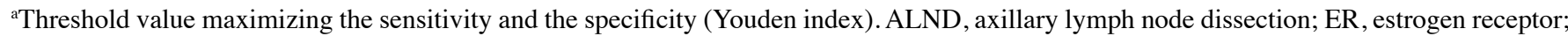
PR, progesterone receptor; HER2, human epidermal growth factor receptor 2; SLN, sentinel lymph node.

underwent ALND. Patients with a negative OSNA result did not undergo further ALND.

OSNA analysis. The median number of SLNs removed was 2 (IQR, 2-4). A total of 123 patients (62\%) had SLN micrometastases, while 74 had SLN macrometastases (38\%). The median number of ALNs removed was 15 (IQR, 13-19.5) with a median of 2 (IQR, 1-3) positive ALNs. A total of 40 patients (20\%) had non-SNL metastases. The patient characteristics according to lymph node status are presented in Table II. A tumor size $>13 \mathrm{~mm}$ localized in the outer quadrant (OQ) or lower-outer quadrant (LOQ) of the breast was more frequent in the group with positive ALND. Two or more positive SLNs were found in all patients with positive ALND. The CK19 mRNA copy number was also higher in the positive ALND group [median, 60,830 (IQR, 5,000-695,000) vs. 1,300 (IQR, 530-6,900)]. The threshold of 4,700 CK19 mRNA copies was found to be the optimal cut-off for distinguishing patients with vs. those without non-SNLs. The value of 5,000 CK19 mRNA copies commonly used to differentiate micrometastases and macrometastases was retained, since only 3 patients had values between 4,700 and 5,000. A total of 30 patients of the group with positive ALND (75\%) had SLN macrometastases vs. only $28 \%$ in the group with negative ALND, corresponding to a specificity of $72 \%(113 / 157)$. The positive predictive value was $40.5 \%(30 / 74)$ and the negative predictive value (NPV) was $92 \%$ (113/123). The factors predictive of positive ALND are presented in Table III, whereas a comparison of the OSNA cut-off of the present study with other alternatives from the literature for prediction of non-SLN metastasis is presented in Table IV.

By multivariate analysis, two parameters remained significantly associated with positive ALND, namely SLN macrometastases $(\mathrm{OR}=8.07,95 \% \mathrm{CI}$ : 3.58-18.23) and tumor localization in the OQ [centered around the 3 o'clock position (left breast) or 9 o'clock position (right breast)] or LOQ 
Table III. Predictive factors for positive axillary lymph node dissection by bivariate and multivariate logistic regression analysis.

\begin{tabular}{|c|c|c|c|c|}
\hline \multirow[b]{2}{*}{ Factors } & \multicolumn{2}{|c|}{ Bivariate analyses } & \multicolumn{2}{|c|}{ Multivariate analysis } \\
\hline & OR $(95 \% \mathrm{CI})$ & P-value & OR $(95 \% \mathrm{CI})$ & $\mathrm{P}$-value \\
\hline Age (per 1-year increase) & $0.98(0.95-1.01)$ & 0.295 & & \\
\hline Body mass index $\geq 30 \mathrm{~kg} / \mathrm{m}^{2}$ & $2.12(0.98-4.61)$ & 0.056 & & \\
\hline Tumor size $>13 \mathrm{~mm}$ & $2.41(1.13-5.16)$ & 0.023 & & \\
\hline Bloom-Richardson histological grade & & 0.551 & & \\
\hline 1 & 1.0 (reference) & & & \\
\hline 2 & $1.51(0.66-3.42)$ & & & \\
\hline 3 & $1.05(0.34-3.20)$ & & & \\
\hline Tumor localization in the outer or lower-outer quadrant & $2.50(1.11-5.60)$ & 0.026 & $2.84(1.14-7.05)$ & 0.025 \\
\hline Ductal carcinoma & $2.31(0.85-6.32)$ & 0.102 & & \\
\hline Copy number $\geq 5,000 / \mu 1$ & $7.70(3.48-17.08)$ & $<0.001$ & $8.07(3.58-18.23)$ & $<0.001$ \\
\hline Positive ER status & $1.57(0.34-7.33)$ & 0.564 & & \\
\hline Positive PR status & $2.08(0.76-5.71)$ & 0.154 & & \\
\hline Positive ER or PR status & $1.57(0.34-7.38)$ & 0.564 & & \\
\hline Positive HER2 status & $0.70(0.15-3.29)$ & 0.650 & & \\
\hline Triple-negative breast cancer & $0.77(0.16-3.68)$ & 0.747 & & \\
\hline
\end{tabular}

ER, estrogen receptor; PR, progesterone receptor; HER2, human epidermal growth factor receptor 2.

$(\mathrm{OR}=2.84 ; 95 \% \mathrm{CI}: 1.14-7.05)$. The AUC was 0.77 (95\% CI: $0.69-0.85)$. Considering that $20 \%$ of the patients had non-SLN metastases in our population (40/197), the estimated probability from the multivariate model was $36 \%$ for patients with SLN macrometastases and tumor outside of the OQ or LOQ, and $61 \%$ for patients with SLN macrometastases and tumor localization within the OQ or LOQ. The estimated probability of positive ALND for patients with micrometastases was $6 \%$ in case of tumors located outside of the OQ or LOQ and $16 \%$ in case of tumors within the OQ or LOQ.

\section{Discussion}

Intraoperative SLN evaluation has limited ability to detect metastases due to the partial evaluation of the node $(10,11)$. SLN histopathological examination is thus performed postoperatively in several centers. Since 2007, the OSNA assay has been used as an objective, simple and automated tool for the intraoperative assessment of whole SLNs. The high concordance of OSNA with histological techniques has been shown in several studies (20-23), as has its high sensitivity and specificity (24). OSNA avoids sampling errors and second-stage surgeries due to false-negative results, without increasing operative time, except in breast-conserving surgery (25).

However, the need for ALND in SLN-positive early breast cancer remains controversial. ALND is a possible cause of morbidity, incurs greater costs and is associated with lower quality of life (26). Furthermore, the selection of adjuvant therapy currently relies more on the characteristics of the primary tumor rather than on the number of affected lymph nodes. Several studies have shown poorer prognosis and a higher recurrence rate in cases with SLN micrometastases without adjuvant therapy $(6,27,28)$. In line with the find- ings of the IBCSG 23-01 trial (5), the American College of Surgeons Oncology Group (ACOSOG) Z0011 randomized trial (16) stated that ALND could be avoided in patients with T1-T2 N0 breast cancer and 1-2 SLN metastases undergoing breast-conserving surgery and receiving adjuvant whole-breast irradiation and adjuvant systemic therapy. In the AMAROS trial (17), the authors demonstrated the non-inferiority of axillary radiotherapy vs. ALND in patients with SLN micro- or macrometastases.

Due to certain limitations in these trials, including a high rate of loss to follow-up (18.6\% in the ACOSOG study), and imbalances in several prognostic characteristics between groups $(29,16)$, several trials are still ongoing to confirm these results (30). The 2015 National Comprehensive Cancer Network guidelines (14) already stated that ALND was not necessary in the population of the ACOSOG trial. Current recommendations in France indicate that ALND is necessary if SLN macro-metastases are present, whereas multidisciplinary discussion is recommended in case of micrometastases (31).

The use of objective tools capable of predicting non-SLN axillary involvement could therefore be useful, at least for patients who do not meet the Z0011 criteria, or who were underrepresented in that trial (for example, patients with invasive lobular carcinoma, estrogen receptor-negative status, or age $<50$ years). An optimal negative cut-off would also help to identify patients who would not benefit from ALND, given that it can safely be omitted if SLN is negative (32).

Many available prediction models for positive ALND are based on factors that cannot be determined preoperatively and are therefore not clinically relevant. The OSNA procedure can be performed during surgery and is an independent predictive factor of potential further axillary metastasis progression, with a good diagnostic capacity [area under the receiver operating characteristics curve (AUC) $=0.77$ in the present study] 
Table IV. Comparison of our OSNA cut-off with other alternatives from literature for prediction of non-SLN metastasis.

\begin{tabular}{|c|c|c|c|c|c|c|c|c|c|c|c|}
\hline Study (Refs.) & $\begin{array}{l}\text { Number } \\
\text { of patients }\end{array}$ & $\begin{array}{l}\text { Threshold } \\
\text { (copies } / \mu \mathrm{l} \text { ) }\end{array}$ & $\mathrm{Se}$ & $\mathrm{Sp}$ & PPV & NPV & $\begin{array}{c}\mathrm{FN}, \\
\mathrm{n}(\%)\end{array}$ & $\begin{array}{c}\mathrm{FP} \\
\mathrm{n}(\%)\end{array}$ & Method & AUC & Problems \\
\hline Present study & $\begin{array}{l}812 \text { patients } \\
197 \text { OSNA+ }\end{array}$ & 5,000 & 75.0 & 72.0 & 40.5 & 91.9 & $\begin{array}{c}10 \\
(8.1)\end{array}$ & $\begin{array}{c}44 \\
(59.5)\end{array}$ & $\begin{array}{l}\text { Maximal } \\
\text { copy } \\
\text { number }\end{array}$ & 0.77 & \\
\hline Peg et al (37) & $\begin{array}{l}697 \text { patients } \\
\text { OSNA+ }\end{array}$ & 15,000 & 76.7 & 55.2 & 41.1 & 85.5 & $14.7 \%$ & & TTL & 0.709 & $\begin{array}{l}\text { T1-T3 breast } \\
\text { tumors. }\end{array}$ \\
\hline $\begin{array}{l}\text { Deambrogio } \\
\text { et al (38) }\end{array}$ & $\begin{array}{l}1,080 \text { patients } \\
194 \text { OSNA+ }\end{array}$ & 7,700 & 78 & 57 & 50 & 83 & $\begin{array}{c}15 \\
(17.4)\end{array}$ & $\begin{array}{c}54 \\
(50)\end{array}$ & & & $\begin{array}{l}\text { T1-T3 breast } \\
\text { tumors. } \\
46 \text { patients with } \\
\text { OSNA+ analysis } \\
\text { did not undergo } \\
\text { further surgery. }\end{array}$ \\
\hline $\begin{array}{l}\text { Heilmann } \\
\text { et al (39) }\end{array}$ & $\begin{array}{l}143 \text { patients } \\
39 \text { OSNA+ }\end{array}$ & 7,900 & 91 & 61 & & & & & & & $\begin{array}{l}\text { T1-T3 breast } \\
\text { tumors. } \\
\text { Part of the lymph } \\
\text { node analyzed } \\
\text { by histology. }\end{array}$ \\
\hline $\begin{array}{l}\text { Terrenato } \\
\text { et al }(20)\end{array}$ & $\begin{array}{l}1,140 \text { patients } \\
318 \text { OSNA+ }\end{array}$ & 2,150 & 94.9 & 51.4 & 46.5 & 95.8 & $\begin{array}{c}5 \\
(4.2)\end{array}$ & $\begin{array}{c}107 \\
(53.5)\end{array}$ & TTL & 0.765 & $\begin{array}{l}\text { No description } \\
\text { of }+\mathrm{I} \text { case } \\
\text { management. } \\
\text { Lack of representation } \\
\text { of cancers other } \\
\text { than ductal or } \\
\text { lobular carcinomas. }\end{array}$ \\
\hline $\begin{array}{l}\text { Nabais } \\
\text { et al (40) }\end{array}$ & $\begin{array}{l}598 \text { patients } \\
58 \text { OSNA+ }\end{array}$ & 190,000 & 73.3 & 74.4 & & 88.9 & & & TTL & 0.805 & $\begin{array}{l}\text { T1-T3 breast } \\
\text { tumors. }\end{array}$ \\
\hline $\begin{array}{l}\text { Banerjee } \\
\text { et al (41) }\end{array}$ & $\begin{array}{l}170 \text { patients } \\
49 \text { OSNA+ }\end{array}$ & 1,400 & & & & & & & & & $\begin{array}{l}\text { T1-T3 breast } \\
\text { tumors. } \\
50 \% \text { of the lymph } \\
\text { node analyzed } \\
\text { by OSNA. }\end{array}$ \\
\hline $\begin{array}{l}\text { Espinosa- } \\
\text { Bravo } \\
\text { et al }(42)\end{array}$ & $\begin{array}{l}306 \text { patients } \\
108 \text { OSNA+ }\end{array}$ & 120,000 & 47 & 85.3 & 56 & 80 & & & TTL & & \\
\hline $\begin{array}{l}\text { Buglioni } \\
\text { et al (43) }\end{array}$ & $\begin{array}{l}709 \text { patients } \\
179 \text { OSNA+ }\end{array}$ & 2,000 & & & & & & & & & $\begin{array}{l}50 \% \text { of the lymph } \\
\text { node analyzed } \\
\text { by OSNA. }\end{array}$ \\
\hline
\end{tabular}

Se, sensitivity; Sp, specificity; PPV, positive predictive value; NPV, negative predictive value; FN, false-negative; FP, false-positive; AUC, area under receiver operating characteristics curve; TTL, total tumor load; OSNA, one-step nucleic acid amplification.

Predictive cut-offs of CK19 mRNA copy number have already been investigated in other studies (20,37-43). Some authors (43) considered the maximal copy number, whereas others $(20,37,40,42)$ considered the total tumor load (TTL), defined by the number of CK19 mRNA copies in all positive SLNs. TTL could be considered as more representative of the tumor cell load, but is linked to the number of SLNs analyzed during the procedure, which depends on the highly variable standard practices in each center. This variability in practices may explain the differences between the cut-offs across published studies.

In some studies $(39,41)$, SLN sections were used for histological evaluation. Our supplementary analysis including the 49 patients with histological analysis of SLN sections confirmed that this practice may lead to possible underestimation of CK19 mRNA total copies. This analysis yielded a cut-off of 3,500 copies [AUC=0.741 (95\% CI: 0.657-0.825), data not shown]. A false-negative result would prevent some 
patients from undergoing ALND. The undervaluation of copy number could also explain the varying cut-offs reported in published studies $(40,41)$. There is potential for bias in our study due to the exclusion of $20+\mathrm{I}$ cases the total copy number of which was not available (33) and because of the 49 cases with histological analysis of the central section of the SLN. Some disadvantages of the OSNA assay must also be considered, such as te inability to conduct further histological analysis.

Shimazu et al (34) proposed an intraoperative nomogram based on tumor size and TTL, but their NPV and AUC were lower compared with those in the present study. Furthermore, a central section was removed for histological examination in one institution.

In our cohort of patients, when the copy number was $<5,000$, 113 patients had no further axillary involvement (92\%) and only 10 patients $(8 \%)$ had positive ALND. These results indicate that ALND can safely be avoided when the tumor is localized outside of the OQ or LOQ of the breast, and the copy number is $<5,000$. A total of 30 ALNDs were positive when CK19 mRNA was $>5,000$ copies $(41 \%)$. These results support the concept that ALND must be considered in this case, particularly when the tumor is in the OQ. We believe that the high cut-offs described by Heilmann et al (39), Deambrogio et al (38) or Peg et al (37) may result in a very high false-negative rate. We herein confirmed that ALND can safely be avoided in patients with tumors in the other quadrants if the CK19 mRNA copy number is $<5,000$. These results are almost in line with previous published studies $(20,38)$, and the copy threshold for OSNA was confirmed based on a large cohort. The present study may also help to overcome certain drawbacks of previous studies $(39,41)$, such as partial evaluation of the node.

Predictive thresholds for non-SLN positivity should be assessed in other cancers, such as cervical cancer, in which pelvic lymphadenectomy results are negative in $>80 \%$ of cases (35). The OSNA assay may also contribute to prognostic evaluation (36).

In conclusion, a cut-off of 5,000 copies for CK19 mRNA combined with tumor localization may represent an intraoperative objective and useful tool for predicting further non-SLN axillary involvement and the need for completion ALND in patients with breast cancer.

\section{Acknowledgements}

Not applicable.

\section{Funding}

No funding was received.

\section{Availability of data and materials}

The datasets used and/or analyzed during the current study are available from the corresponding author on reasonable request.

\section{Authors' contributions}

Conceptualization, JLM, PR and FM; methodology, AH and JLM; validation and interpretation of raw data, AH, FM and
JLM; formal analysis, JS; data collection, MK, MR, MH, PG and HP; resources, PR, FM and JLM; data curation, MK and $\mathrm{AH}$; original manuscript draft preparation, HP; manuscript review and editing, $\mathrm{AH}$; visualization, $\mathrm{HP}$ and $\mathrm{AH}$; supervision, AH; project administration, JLM, AL and AH. All the authors have read and approved the final version of the manuscript for publication.

\section{Ethics approval and consent to participate}

All patients provided informed oral consent and a signed a non-opposition form and the study was approved by the Ethics Committee of the ICL (CAV-2009-osna).

\section{Patient consent for publication}

Not applicable.

\section{Competing interests}

The authors declare that they have no competing interests.

\section{References}

1. Bray F, Ferlay J, Soerjomataram I, Siegel RL, Torre LA and Jemal A: Global cancer statistics 2018: GLOBOCAN estimates of incidence and mortality worldwide for 36 cancers in 185 countries. CA Cancer J Clin 68: 394-424, 2018

2. Fisher B, Bauer M, Wickerham DL, Redmond CK, Fisher ER, Cruz AB, Foster R, Gardner B, Lerner H, Margolese R, et al: Relation of number of positive axillary nodes to the prognosis of patients with primary breast cancer. An NSABP update. Cancer 52: 1551-1557, 1983.

3. Moore MP and Kinne DW: Axillary lymphadenectomy: A diagnostic and therapeutic procedure. J Surg Oncol 66: 2-6, 1997.

4. Jakub JW, Bryant K, Huebner M, Hoskin T, Boughey JC, Reynolds $C$ and Degnim AC: The number of axillary lymph nodes involved with metastatic breast cancer does not affect outcome as long as all disease is confined to the sentinel lymph nodes. Ann Surg Oncol 18: 86-93, 2011.

5. Galimberti V, Cole BF, Zurrida S, Viale G, Luini A, Veronesi P, Baratella P, Chifu C, Sargenti M, Intra M, et al; International Breast Cancer Study Group Trial 23-01 investigators: Axillary dissection versus no axillary dissection in patients with sentinel-node micrometastases (IBCSG 23-01): A phase 3 randomised controlled trial. Lancet Oncol 14: 297-305, 2013.

6. Reed J, Rosman M, Verbanac KM, Mannie A, Cheng Z and Tafra L: Prognostic implications of isolated tumor cells and micrometastases in sentinel nodes of patients with invasive breast cancer: 10-year analysis of patients enrolled in the prospective East Carolina University/Anne Arundel Medical Center Sentinel Node Multicenter Study. J Am Coll Surg 208: 333-340, 2009.

7. Carlo JT, Grant MD, Knox SM, Jones RC, Hamilton CS Livingston SA and Kuhn JA: Survival analysis following sentinel lymph node biopsy: A validation trial demonstrating its accuracy in staging early breast cancer. Proc Bayl Univ Med Cent 18: 103-107, 2005.

8. Chu PG and Weiss LM: Keratin expression in human tissues and neoplasms. Histopathology 40: 403-439, 2002.

9. Tsujimoto M, Nakabayashi K, Yoshidome K, Kaneko T, Iwase T, Akiyama F, Kato Y, Tsuda H, Ueda S, Sato K, et al: One-step nucleic acid amplification for intraoperative detection of lymph node metastasis in breast cancer patients. Clin Cancer Res 13: 4807-4816, 2007.

10. Li D, Xu X, Chen J, Chen J, Yang B, Yang W, Xu W, Wu J and Shi D: Utility of one-step nucleic acid amplification (OSNA) assay in detecting breast cancer metastases of sentinel lymph nodes in a Chinese population. Breast Cancer 22: 135-140, 2015.

11. Leidenius MHK, Krogerus LA, Toivonen TS and Von Smitten KJ: The feasibility of intraoperative diagnosis of sentinel lymph node metastases in breast cancer. J Surg Oncol 84: 68-73, 2003. 
12. Raia-Barjat T, Trombert B, Khaddage A, Douchet C, Seffert P, Peoc'h M, Falk AT, Magné N and Chauleur C: OSNA (one-step nucleic acid amplification) sentinel lymph node intraoperative molecular analysis in breast cancer: A cost-benefit analysis. Med Oncol 31: 322, 2014

13. Castellano I, Macrì L, Deambrogio C, Balmativola D, Bussone R, Ala A, Coluccia C and Sapino A: Reliability of whole sentinel lymph node analysis by one-step nucleic acid amplification for intraoperative diagnosis of breast cancer metastases. Ann Surg 255: 334-342, 2012.

14. Saruta Y and Puig-Junoy J: Cost and budget impact analysis of an accurate intraoperative sentinel lymph node diagnosis for breast cancer metastasis. Appl Health Econ Health Policy 14: 323-335, 2016.

15. Klingler S, Marchal F, Rauch P, Kenouchi O, Chrétien AS, Genin P, Leroux A and Merlin JL: Using one-step nucleic acid amplification (OSNA) for intraoperative detection of lymph node metastasis in breast cancer patients avoids second surgery and accelerates initiation of adjuvant therapy. Ann Oncol 24: 2305-2309, 2013.

16. Giuliano AE, Ballman KV, McCall L, Beitsch PD, Brennan MB Kelemen PR, Ollila DW, Hansen NM, Whitworth PW, Blumencranz PW, et al: Effect of axillary dissection vs no axillary dissection on 10-year overall survival among women with invasive breast cancer and sentinel node metastasis: The ACOSOG Z0011 (Alliance) Randomized Clinical Trial. JAMA 318: 918-926, 2017.

17. Donker M, van Tienhoven G, Straver ME, Meijnen $P$, van de Velde CJ, Mansel RE, Cataliotti L, Westenberg AH, Klinkenbijl JH, Orzalesi L, et al: Radiotherapy or surgery of the axilla after a positive sentinel node in breast cancer (EORTC 10981-22023 AMAROS): A randomised, multicentre, open-label, phase 3 non-inferiority trial. Lancet Oncol 15: 1303-1310, 2014.

18. Sobin LH and Wittekind CH (eds): UICC: TNM Classification of Malignant Tumors. 6th edition. Wiley-Liss, New York, NY, 2002.

19. Sauerbrei W and Schumacher M: A bootstrap resampling procedure for model building: Application to the Cox regression model. Stat Med 11: 2093-2109, 1992

20. Terrenato I, D'Alicandro V, Casini B, Perracchio L, Rollo F, De Salvo L, Di Filippo S, Di Filippo F, Pescarmona E, Maugeri-Saccà M, et al: A cut-off of 2150 cytokeratin 19 mRNA copy number in sentinel lymph node may be a powerful predictor of non-sentinel lymph node status in breast cancer patients. PLoS One 12: e0171517, 2017

21. Tamaki Y: One-step nucleic acid amplification (OSNA): Where do we go with it? Int J Clin Oncol 22: 3-10, 2017.

22. Snook KL, Layer GT, Jackson PA, de Vries CS, Shousha S, Sinnett HD, Nigar E, Singhal H, Chia Y, Cunnick G, et al; OSNA Study Group: Multicentre evaluation of intraoperative molecular analysis of sentinel lymph nodes in breast carcinoma. Br J Surg 98: 527-535, 2011

23. Cserni G: Intraoperative analysis of sentinel lymph nodes in breast cancer by one-step nucleic acid amplification. J Clin Pathol 65: 193-199, 2012.

24. Shi F, Liang Z, Zhang Q, Wang C and Liu X: The performance of one-step nucleic acid amplification assay for intraoperative detection of sentinel lymph node macrometastasis in breast cancer: An updated meta-analysis. Breast 39: 39-45, 2018.

25. Chaudhry A, Williams S, Cook J, Jenkins M, Sohail M, Calder C, Winters ZE and Rayter Z: The real-time intra-operative evaluation of sentinel lymph nodes in breast cancer patients using One Step Nucleic Acid Amplification (OSNA) and implications for clinical decision-making. Eur J Surg Oncol 40: 150-157, 2014.

26. Mansel RE, Fallowfield L, Kissin M, Goyal A, Newcombe RG, Dixon JM, Yiangou C, Horgan K, Bundred N, Monypenny I, et al Randomized multicenter trial of sentinel node biopsy versus standard axillary treatment in operable breast cancer: The ALMANAC Trial. J Natl Cancer Inst 98: 599-609, 2006.

27. Tjan-Heijnen VC, Pepels MJ, de Boer M, Borm GF, van Dijck JA, van Deurzen $\mathrm{CH}$, Adang EM, Menke-Pluymers MB, van Diest PJ and Bult P: Impact of omission of completion axillary lymph node dissection (cALND) or axillary radiotherapy (ax RT) in breast cancer patients with micrometastases $(\mathrm{pN} 1 \mathrm{mi})$ or isolated tumor cells (pNO(i+)) in the sentinel lymph node ( $\mathrm{SN})$ : Results from the MIRROR study. J Clin Oncol 27 (Suppl 15): CRA506-CRA506, 2009.

28. Pepels MJ, de Boer M, Bult P, van Dijck JA, van Deurzen $\mathrm{CH}$, Menke-Pluymers MB, van Diest PJ, Borm GF and Tjan-Heijnen VC: Regional recurrence in breast cancer patients with sentinel node micrometastases and isolated tumor cells. Ann Surg 255: 116-121, 2012.
29. Huang T-W, Kuo KN, Chen K-H, Chen C, Hou WH, Lee WH, Chao TY, Tsai JT, Su CM, Huang MT, et al: Recommendation for axillary lymph node dissection in women with early breast cancer and sentinel node metastasis: A systematic review and meta-analysis of randomized controlled trials using the GRADE system. Int J Surg 34: 73-80, 2016.

30. Houvenaeghel G, Cohen M, Raro P, De Troyer J, de Lara CT, Gimbergues P, Gauthier T, Faure-Virelizier C, Vaini-Cowen V, Lantheaume S, et al; Others investigators (SERC trial group): Overview of the pathological results and treatment characteristics in the first 1000 patients randomized in the SERC trial: Axillary dissection versus no axillary dissection in patients with involved sentinel node. BMC Cancer 18: 1153, 2018.

31. Dauplat MM, E. Barranger E, Classe JM, Toledano A and Houvenaeghel G: L'exploration et le traitement de la région axillaire des tumeurs infiltrantes du sein. Oncologie 15: 589-592, 2013.

32. Veronesi U, Paganelli G, Galimberti V, Viale G, Zurrida S, Bedoni M, Costa A, de Cicco C, Geraghty JG, Luini A, et al: Sentinel-node biopsy to avoid axillary dissection in breast cancer with clinically negative lymph-nodes. Lancet 349: 1864-1867, 1997.

33. Horimoto Y, Tanabe M, Kazuno S, Miura Y, Mogushi K, Sonoue H, Arakawa A, Kajino K, Kobayashi T and Saito M: Elucidation of inhibitory effects on metastatic sentinel lymph nodes of breast cancer during One-Step Nucleic Acid Amplification. Sci Rep 8: 7563, 2018.

34. Shimazu K, Sato N, Ogiya A, Sota Y, Yotsumoto D, Ishikawa T, Nakamura S, Kinoshita T, Tsuda H, Ohi Y, et al: Intraoperative nomograms, based on one-step nucleic acid amplification, for prediction of non-sentinel node metastasis and four or more axillary node metastases in breast cancer patients with sentinel node metastasis. Ann Surg Oncol 25: 2603-2611, 2018.

35. Bizzarri N,Pedone Anchora L,Zannoni GF, Santoro A, Valente M, Inzani F, Gallotta V, Conte C, Chiantera V, Fanfani F, et al: Role of one-step nucleic acid amplification (OSNA) to detect sentinel lymph node low-volume metastasis in early-stage cervical cancer. Int J Gynecol Cancer 30: 364-371, 2020.

36. Shimazu K, Miyake T, Okuno J, Naoi Y, Tanei T, Shimoda M, Kagara N, Kim SJ and Noguchi S: One-step Nucleic Acid Amplification can identify sentinel node-negative breast cancer patients with excellent prognosis. Anticancer Res 39: 1447-1454, 2019.

37. Peg V, Espinosa-Bravo M, Vieites B, Vilardell F, Antúnez JR, de Salas MS, Delgado-Sánchez JJ, Pinto W, Gozalbo F, Petit A, et al: Intraoperative molecular analysis of total tumor load in sentinel lymph node: A new predictor of axillary status in early breast cancer patients. Breast Cancer Res Treat 139: 87-93, 2013.

38. Deambrogio C, Castellano I, Paganotti A, Zorini EO, Corsi F, Bussone R, Franchini R, Antona J, Miglio U, Sapino A, et al: A new clinical cut-off of cytokeratin 19 mRNA copy number in sentinel lymph node better identifies patients eligible for axillary lymph node dissection in breast cancer. J Clin Pathol 67: 702-706, 2014.

39. Heilmann T, Mathiak M, Hofmann J, Mundhenke C, van Mackelenbergh M, Alkatout I, Wenners A,Eckmann-Scholz C and Schem C: Intra-operative use of one-step nucleic acid amplification (OSNA) for detection of the tumor load of sentinel lymph nodes in breast cancer patients. J Cancer Res Clin Oncol 139: 1649-1655, 2013

40. Nabais C, Figueiredo J, Lopes P, Martins M and Araújo A: Total tumor load assessed by one-step nucleic acid amplification assay as an intraoperative predictor for non-sentinel lymph node metastasis in breast cancer. Breast 32: 33-36, 2017.

41. Banerjee SM, Michalopoulos NV, Williams NR, Davidson T, El Sheikh S, McDermott N, Tran-Dang MA, Davison S and Keshtgar MR: Detailed evaluation of one step nucleic acid (OSNA) molecular assay for intra-operative diagnosis of sentinel lymph node metastasis and prediction of non-sentinel nodal involvement: Experience from a London teaching hospital. Breast 23: 378-384, 2014.

42. Espinosa-Bravo M, Sansano I, Pérez-Hoyos S, Ramos M, Sancho M, Xercavins J, Rubio IT and Peg V: Prediction of non-sentinel lymph node metastasis in early breast cancer by assessing total tumoral load in the sentinel lymph node by molecular assay. Eur J Surg Oncol 39: 766-773, 2013

43. Buglioni S, Di Filippo F, Terrenato I, Casini B, Gallo E, Marandino F, Maini CL, Pasqualoni R, Botti C, Di Filippo S, et al: Quantitative molecular analysis of sentinel lymph node may be predictive of axillary node status in breast cancer classified by molecular subtypes. PLoS One 8: e58823, 2013. 